\title{
UM MAQUIAVEL DIFERENTE?
}

\author{
LUIGI CASTAGNOLA \\ Universidade Federal do Paraná
}

\begin{abstract}
Sumário: 1. Maquiavel: Tema polêmico. - 2. Perfil biográfico. - 3. O literato, o lingüista, o historiador. - 4. O pensodor politico: II Principe. - 5. Considerações críticas.
\end{abstract}

\section{MAQUIAVEL: TEMA POLEMICO}

Tanto nomini nullum par elogium. Tão insólito elogio está gravado, desde 1780, no monumento erguido sôbre o túmulo de Nicolau Maquiavel (1469-1527), na Igreja de Santa Cruz, em Florença. Esse monumento é bom lembrar que foi levantado por iniciativa de dois estrangeiros, o inglês Lord Cooper e o grão-duque Pedro Leopoldo de Lorena.

Os Florentinos parecem primar no costume de perseguir ou menosprezar seus ilustres cidadãos quando vivos, e louvá-los desmedidamente quando mortos, após se tornarem vultos de fama universal. O caso de Dante parece repetir-se, de certo modo e embora em grau menor, também com Maquiavel. O primeiro foi despojado de seus direitos políticos, condenado à morte e banido do território de Florença; o segundo também foi afastado punitiva e repetidamente de sua atividade política e condenado a viver fora da cidade, na sua quinta do Albergàccio.

Os dois famosos florentinos utilizaram seu destêrro político paro escreverem as obras que os tornariam afamados entre os homens e obrigariam seus cidadãos a se penitenciarem. Com efeito, Dante compôs no exílio a Divina Comédia e Maquiavel II Príncipe.

$\mathrm{Na}$ literatura italiana é bem conhecido o fenômeno poético chamado petrarquismo: vasta e persistente corrente literária que se inspira na lírica cristalina, amorosa e suspirosa de Petrarca, imitando-o teimosamente, o mais das vêzes de um modo não autêntico e, por isso mesmo, artificial. Na literatura da filosofia política - e na praxe política também - é mais conhecido ainda o fenômeno chamado maquiavelismo: palavra carregada de 
múltiplas e confusas significações, mas que se costuma, habitualmente, usar para indicar um sistema de filosofia e técnica politica conforme o qual tudo é considerado permitido e legítimo a fim de alcançar, conservar e aumentar o poder. E como com o petrarquismo amiúde se confunde Petrarca, assim com o maquiavelismo se confunde Maquiavel. Mas como é êrro grave confundir Petrarca com o petrarquismo, assim é grave êrro confund ir Maquiavel com o maquiavelismo. "Explica-se, destarte, como Maquiavel foi diversamente julgado e sempre teve seus acusadores e seus defensores" (1).

Faz-se mister salientar, contudo, que o assunto versado em II Principe, por si só, é mais do que suficiente para que Maquiavel continue sendo um tema polêmico no mundo da cultura.

A Igreja Católica, desde cedo, condenou as doutrinas politicas de Maquiavel, cujas obras foram tôdas incluídas no Index dos livros proibidos, em 1559. Apesar disto, os.protestantes, nos agitados e agora longinquos primórdios de suas lutas religiosas com os católicos, quiseram ver em Maquiavel, sem nenhuma motivação justificável, mais um expoente das intransigentes teorios papistas. E, ainda hoje, "na língua inglêsa - embora por brincadeira e sem mencionar-lhe a etimologia - é usada a locução the old Nick, o velho Nicolau, para indicar o diabo" (2).

Papini, no estilo marcante de sua prosa conhecidamente desabrida, lembra que "a mais famosa confutação do Principe foi escrita por aquêle imundo (3) rei prussiano, Frederico o Grande, que ampliou seu reino à fôrça de traiçōes e foi o primeiro autor do desmembramento da Polônia" (4).

Por outro lado, o ensinamento político de Maquiavel nunca foi esquecido, e homens de govêrno entre os mais célebres leram com atenção Maquiavel. Entre êles mencionamos Carlos V, na Espanha; Catarina de Médicis e Richelieu, na França; Cristina, rainha da Suécia.

$\mathrm{Na}$ segunda década do século XVII, Trajono Boccalini faz uma defesa original de Maquiavel. Em seus maliciosos e paradoxais Ragguagli di Parnaso faz com que o próprio Maquiavel se defenda diante do tribunal de Apolo. E' uma defesa fantástica, travêssa e, afinal, inútil, pois Maquiavel acaba sendo condenado pelos sisudos magistrados da côrte do Parnaso; mas ela nos faz conhecer o que pensava Boccalini, e muitos outros de sua época, a respeito de Maquiavel. Eis o trecho mais característico:

1) Rosário TOSTO, Hisłória da Literatura Italiana, tradução de Luígi CASTAGNOLA, Petrópolis, 1963, vol. II, p. 49.

2) Mário BONFANTINI, em Lo Letteratura Italiana - Storia e Testi, Milão, 1954, vol. 29 , p. XV.

3) Popini escrevia em 1916, duronte o primeira guerra mundial.

4) Giovanni PAPINI, Opere-Ritratti Italiani, Florença, 1944, vol. XII, p. 95. 
"Eis aqui presente, ó Sire dos literatos, aquêle Nicolau Maquiavel que foi condenado como sedutor e corruptor do gênero humano e como semeador de escandalosos preceitos políticos. $\mathrm{Eu}$, no entanto, não pretendo defender meus escritos; antes, sou - primeiro a condená-los e acusá-los pùblicamente como ímpios e cheios de cruéis e execrandos ensinamentos de governar os estados. De modo que, se a doutrina que dei à imprensa é invenção de minha cabeça e são preceitos novos, peço que, agora mesmo, seja executada contra mim, irremissivelmente, a sentença proferida pelos juízes. Mas se meus escritos encerram tãosòmente os preceitos políticos e aquelas normas de governar os estados que eu tirei das lições de alguns príncipes (que se Vosso Majestade me der licença, chamarei pelo nome neste lugar), dos quais não se pode falar mal sem correr perigo de morte, que justiça é essa que pretende sejam considerados sacrossantos os que inventaram a louca e maldita política escrita por $\mathrm{mim}$, e eu, que apenas a publiquei, deva ser tido por ribaldo e ateísta? Pois, na verdade, não estou vendo a razão pela qual seja bem feito adorar como santo o original, e atirar à fogueira a sua cópia como sendo coisa execrável" (5).

Paulatinamente o pensamento e as obras de Maquavel entraram a fazer parte do mundo da cultura, e lá estão encaixados como alvo de polêmicas sempre renascentes. Em tempos mais próximos de nós, foi abandonado o costume de condenar fanàticamente Maquiavel; como que por reação, apareceram outrossim, de vez em vez, habilidosas tentativas de reabilitação, escritas por autores mais desejosos de incensar determinados sistemas de governos totalitários do que movidos por interêsses de pura investigação científica. Tentativas de reabilitação inspiradas, por vêzes, em filosofias idealistas que pressupõemi ilusòriamente, ser a política separada da ética. Assim, Raya e Russo, por exemplo, falam de Maquiavel como do descobridor da técnica política (6). Sansone, na esteira da filosofia crociana, afirma que "cabe a Maquiavel, na história do espírito moderno, o mérito de ter fundado a ciência política, e não no sentido de que êle, por primeiro, se tenha voltado para os problemas do estado, mas no sentido de que êle, por primeiro, entendeu a política como distinta da moralidade e autônoma com respeito a ela" (7). Constituem uma clara apologia da política maquiavélica as palavras seguintes: "Os preceitos "não matar" e "não roubar", que são os pilares de tôda ética, são inadmissíveis em política. Aplicados ao pé da

5) Traiano BOCCALINI, Ragguagli di Parnaso, Cent. I, ragg. 89.

6) Cf. Gino RAYA, Storia della Letteratura Italiona, Milāo, 1953, p. 292; Luígi RUSSO, Antologia Machiavellica, Florença, 1931.

7) Mário SANSONE, Storia della Lettaratura Italiano, Milāo-Messina, 1957, ps. 196-197. 
letra, significariom a condenaçã̃o e a abolição da guerra, que é a própria vida do Estado... O delito político não é, pròpriamente falando, um delito. A moral o incrimina com a sua lei; a política o exculpa em virtude de uma outra lei, que é a da salvação do Estado" (8).

Por mais habilidosas que sejam estas formas polêmicas de defesa de Maquiavel, não conseguem convencer. A fim de ter certeza disto, é suficiente ler o capítulo quinto de Lineamenti di Filosofia Politica, que Petruzzellis dedica ao maquiavelismo (9). Gonella, atacando frontalmente a estatolatria contida na passagem de Maggiore, pouco acima relatada, escreve com veemência: "Estas palavras, que, se não fôssem ditas a sério, poderiam caricaturar muito bem o maquiavelismo, servem para evidenciar, de forma crua, o absurdo do divórcio entre política e ética, pondo a nu as mais repugnantes e grotescas consequiências dêsse divórcio" (10). Uma voz abalizada levanta-se na Alemanha dêste após-guerra para não aceitar as doutrinas maquiavélicas e recusar as tentativas de sua defesa. $E^{\prime}$ uma voz preciosa, porque vem carregada da experiência trágica de quem viveu momentos políticos que bem se poderiam dizer inspirados em Maquiavel. "Schopenhauer e outros foram de opiniāo, que Maquiavel só se ocupou com a técnica, política como tal, não com a problemática ética (...). Mas nem é êsse o sentido do Principe, nem a posteridade assim entendeu o livro. Maquiavel recomendou, de tôdas as formas, na atividade política e prática, meios imorais e fins imorais (...). Maquiavel se deixa absorver, sem quaisquer escrúpulos, pelo utilidade política. $E$, tendo sempre em vista a utilidade politica e considerando-a decisiva, sugere êle aquela separação moderna da política da moral, que deu ocasiõo a tantas infâmias e atrocidades (...). Poderíamos desenvolver uma técnica da propaganda, da fabricaçāo da moeda falsa, do gôzo, do luxo e de coisas semelhantes. De tal modo tudo escaparia à moral, mesmo a vida privoda, só para a qual ela deveria servir, segundo querem muitos. Ora, a moral ou é uma regra para tôdas as ações humanas, absolutamente e sob tôdas as formas, ou ela não é nada. Maquiavel era cego perante a universalidade dos princípios morais. $E$ aí está um fundamental e, como cremos, erróneo pressuposto do maquiavelismo" (11). Outra voz, não menos autorizada, levanta-se na França e ecoa pelas

8) G. MAGGIORE, La Politica, Bolonha, 1941, ps. 31-32.

9) Nicola PETRUZZELLIS, Lineamenti di Filosofia Politica, Bari, 1951, ps. 108-135.

10) Guido GONELLA, Bases de umo Ordem Social, tradução de Afonso J. ROCHA, Petrópolis, 1947, p. 152.

11) Johannes HIRSCHBERGER, História da Filosofia Moderna, tradução de Alexandre CORREIA, Sāo Paulo, 1960, ps. 62-63. 
universidades norte-americanas contra a concepção maquiavélica da vida política. "Não nos deixemos enganar pela sofística maquiavélica. Dizem os maquiavélicos que a justiça e o respeito pelos valores morais significam fragilidade e destruição, e que a fôrça só vale quando é levada a padrão supremo da existência política. Isto é falso. Não sòmente, como vimos, é o mal incapaz de ter êxito com o decorrer dos tempos, bem como a fôrça igualmente se enfraquece quando não se apóia na justiça; -. mas é fato que, aqui e agora, a fôrça pode existir juntamente com a justiça, e o poder das nações que lutam pela liberdade pode mesmo ser maior do que o das nações que lutam pela escravidão. A segunda guerra mundial foi disso uma prova" (12).

Pelo visto, Maquiavel foi e continuará a ser tema polêmico. Os motivos e a origem destas polémicas prendem-se ao fato de que II Principe trata de problemas que os homens resolvem diferentemente, conforme os ventos políticos que sopram. Também deve ser procurada a fonte de tanta polêmica maquiavélica no fato de que tão freqüente e errôneamente se confunde com Maquiavel o maquiavelismo: palavra proteiforme que, de vez em vez, é tomada para significar, como bem salientou um filósofo da atualidade, ora "o pensamento de Maquiavel, por alguns reduzido, mais ou menos orgânicamente, a sistema; ora o pensa. mento dos continuadores e apologistas de Maquiavel; ora a praxe política que remonta, com razão ou sem razão, a Maquiavel" (13).

Tudo isto vem mostrar, afinal, que a figura de Maquiavel, sem dúvida avultante no mundo da cultura, está ainda envolvida em confusões. O quinto centenário do nascimento de Maquiavel oferece oportunidade para investigações e esclarecimentos sôbre a verdadeira fisionomia do secretário florentino. Embora duvidando que Maquiavel deixe de continuar a ser um tema polêmico sempre vivo e apaixonante, o estudo sereno e objetivo dos problemas por êle versados, hoje como ontem tão prementes para a paz e o progresso entre os povos, poderá levar êstes a terem um conhecimento mais consciente e amadurecido de como podem Ser resolvidos, humanamente e não selvajamente, os graves e grandes conflitos da convivência social. Poderá, também, reduzir às justas proporções "a fama de canalha" que Maquiavel granjeou na opinião dos que, lendo seus livros, viram "neste florentino claro e sêco, sob aparências humanas, o Belfagor de sua novela, ou algum outro arcediabo vindo do inferno à terra a malícia mostrar" (14). Destarte, também Maquiavel poderá ter contribuido, com suas doutrinas tão cruéis, para o melhoramento da humanidade.

12) Jacques MARITAIN, O Homem e Estodo, tradução de Alceu Amoroso LIMA, Rio de Janeiro, 1959, p. 75.

13) Nicola PETRUZZELLIS, ob. cit., p. 108.

14) Giovanni PAPINI, ob. cit., ps. $88-89$. 


\section{PERFIL BIOGRAFICO}

Nicolau Maquiavel nasceu em Florença, em 1469. Sua família pertencia, provàvelmente, à pequena nobreza (15); alguns de seus antepassados foram magistrados da república florentina. O pai foi jurisconsulto; a mãe era mulher culta e religiosa. Embora pouco se saiba a respeito de sua mocidade, teve, por certo, uma boa formação humanística. Estudou porque quis e não porque o mandaram estudar. Dai sua cultura ser um tanto fragmentária e limitada aos assuntos que o interessavam, sendo êsses os de história, política e literatura.

Tinha nove anos quando estourou a conjuraçāo dos Pazzi, em que foi apunhalado e morto, na igreja de Santa Maria del Fiore, Julião de Médicis (1478), e viu enforcados nas janelas do Palácio do Govêrno três dos conjurados. Passou a mocidade em Florença, durante o govêrno de Lourenço o Magnífico, que foi uma época de esplendor político e literário. la crescendo e interessando-se pelas coisas públicas, que entraram numa situação trágica logo depois da morte de Lourenço de Médicis, a qual se deu no mesmo ano da descoberta da Américo (1492). Em 1494, Carlos VIII desceu à Itália e ocupou Florença; o povo, revoltado contra os Médicis, expulsou-os do poder (1494); as tropas francesas atrovessaram e pilharam a Itália, causando desordens por tôda parte; em Florença era proclamada a república popular, orientada espiritualmente pelo famoso frade dominicano Jerônimo Savonarola (1494). Nem assim a cidade teve paz. As lutas partidárias e a firme atitude de Savonarola contra o papa Alexandre VI tiveram um dramático desfecho: a morte de Savonarola na fogueira, numa praça de Florença (1498). Maquiavel presenciou êsses acontecimentos. Em 1498, pressionado também pela sua precária situação econômica, mas acima de tudo levado pelo desejo de tomar parte na política, Maquiavel solicitou um emprêgo ao govêrno republicano. Foi nomeado então secretário da segunda Chancelaria. Ingressou destarte na política ativo, "cibo che solum é mio e che io nacqui per lui" (16), conforme escreveu ao embaixador Francisco Vettori seu amigo.

Foram diversos os encargos que recebeu, mas todos de não muita importância; sempre foi um subalterno. "Sua vida foi, em substância, medíocre e sua atividade quase insignificante" (17). O fato de ter morrido na miséria, depois de ter dedicado quase tôda o sua vida à política, vem mostrar a natureza especulativa

15) Cf. Rosário TOSTO, Storia della Letterotura Italiana, Florença, 1951, vol. I, p. 76, nota (1).

16) Niccolò MACHIAVELLI, Opere, na coleção La Letteratura Italiana Storia e Testi, Milāo, 1954, vol. 29, p. 1111.

17) Rosário TOSTO, op. cit., p. 85. 
e idealista de sua atividade política. Mencionamos êsses encargos e essas missões diplomáticas porque foram ocasiões que o levaram a escrever a maior parte de suas obras. O que vem mostrar ainda que Maquiavel nāo foi, pròpriamente, um literato de profissão.

O primeiro encargo que recebeu o "secretário florentino" foi de ir junto de Appiani, governador de Piombino, que Florença desejava ter como aliado político. A ordem era de fazer muitas promessas, sem tomar nenhum compromisso. Em 1499, mais ou menos com as mesmas finalidades, é enviado junto de Catarina Sforzo, condessa de Imola e Forlí.

De volta a Florença, tem que se ocupar com a guerra contra a cidade de Pisa e escreve o Discorso sopra le cose di Pisa (1499). As desordens das tropas mercenárias francesas na guerra contra Pisa foram o motivo de sua ida à França, para exigir que Luís XII tomasse providências. Tendo conseguido sòmente vagas promessas, voltou a Florenca desgostoso com os franceses, e convencido de que um estado, para ser forte e defender seus direitos, não deve assoldadar milícias estrangeiras, mas possuir um exército nacional. Essa idéia nunca mais será abandonada por Maquiavel.

No meio de outros modestos encargos, achou o tempo para se casar com Marieta Corsini (1502), que êle considerou espôsa fiel e afetuosa.

Entrementes César Borja, o célebre duque Valentino, ocupa uma parte do território da república florentina, contra a qual se levantam também Arezzo e os povos do Vale de Chiana. Maquiavel é enviado junto do duque para negociar e escreve Del modo di trattare i popoli della Val di Chiana ribellati (1502). Volta de nôvo junto do Valentino (1502-1503), com a ordem de ficar olhando e informar o govêrno da república. Maquiavel conhece então de perto o cruel Valentino e admira sua extraordinária decisão em resolver os negócios políticos e militares. Presenciou algumas das façanhas do duque; pareceram-lhe admiráveis e muito o impressionaram. Entre outras, viu a matança de Senigállia em que o Valentino, com o mais frio cinismo, mandou executar proditòriamente alguns inimigos. O fato pareceu a $\mathrm{Ma}$ quiavel "raro e admirável" e contou-o na obrazinha Descrizione del modo tenuto dal Duca Valentino nello ammazzare Vitellozzo Vitelli, Oliverotto da Fermo, il Signor Pagolo e il duca di Gravina Orsini (1503).

Já em Florença, compôs o Discorso sopra la provvisione del danaio (1503), cujo assunto é de caráter financeiro. No comêço, entretanto, fala do perigo em que se acha um país desarmado, obrigado a recorrer a tropas mercenárias para se defender.

Em fins de 1503 foi enviado a Roma para observar o andamento do conclave, após a morte de Alenxadre VI. No ano seguinte vai a Lião a fim de solicitar a intervenção da França 
contra os espanhóis e os venezianos que punham e dispunham na Itália. Nada conseguindo, volta a Florença e ocupa-se com a guerra contra Pisa. Entrementes escreve o Decennale primo (1504), uma cronistória em tercetos sôbre os acontecimentos de 1494 até 1504.

Maquiavel continua com a idéia fixa de que Florença deve ter um exército próprio e, afinal, consegue ganhar a aprovação do govêrno. Entre 1505 e 1507, forma o primeiro exército do república e escreve o Discorso dell'ordinare lo Stato di Firenze e - Discorso sopra l'ordinanza milizia fiorentina. E' criada uma nova magistrotura, que nós, hoje, chamaríamos de "ministério da guerra", da qual Maquiavel, naturalmente, é nomeado secretário. E' preciso dizer que a idéio de Maquiavel encontrou sérias dificuldades, também por ser o povo hostil ao alistamento obrigatório. O tempo, entretanto, devia mostrar o quanto estava certo Maquiavel. Hoje em dia não há mais pais que não tenha seu exército nacional e desapareceram as tropas mercenárias, tão comuns naquela época.

Em 1507, atravessando a Suíça, alcança a côrte de Maximiliano da Áustria, que devia ir à Itália paro ser coroado imperador. Teve assim a oportunidade de conhecer os costumes e as cidades da Germânia e escrever o Rapporto di cose della Magna (18).

Em Florenca, mais uma vez, tem que se ocupar com a guerra de Pisa; a cidade, completamente exausta, acaba por render-se (1509). O mérito de Maquavel estava fora de dúvidas; mas o govêrno florentino achava que não se devia dar tanta importância a um simples secretório. No mesmo ano, foi enviado a Mântua, para pagar uma quantia que Florença devia ao imperador Maximiliano, e escreveu a primeira parte do Docennale secondo (1504-1509), que ficou inacabodo.

Com a finalidade de abrandar a tensão entre o papa e o rei Luis XII, em 1510, foi enviado à França. Estudou então de perto os costumes dos franceses, para com os quais não tinha simpatia, e julgou-os maus políticos, "umilissimi nella cattiva fortuna, nella buona insolenti". Condensou suas experiências nos Ritratti delle cose di Francia (1510). Estava de nôvo na França no ano seguinte, a fim de tornar amistosas as relaçōes entre o papado e o rei francês, conforme o interêsse político de Florença mandava.

Os Médicis, que nunca mediram esforços para voltar ao govêrno de Florença, conseguiram retomar o poder em 1512. Maquiavel iludia-se pensando que o deixariam continuar no seu cargo. Mas os novos senhores tinham opinião diferente. Foi êle afastado completamente da vida politica; até foi prêso e tortu-

18) Mais tarde, Maquiavel modificou a obra, dando-lhe o titulo seguinte: Ritratti delle cose dell'Alemagna (1512). 
rado e, finalmente, condenado ao destêrro. Abalado, triste e pobre, retirou-se para a sua quinta do Albergaccio. Na solidão e na miséria do exílio, Maquiavel escreveu as duas obras que the dariam famo entre os homens: II Principe (1513) e os Discorsi sopra la prima deca di Tito Livio (iniciados em 1513, mas acabados mais tarde).

No exílio político, Maquiavel consumia-se de mágoa e saudade, recorrendo a amigos porque interpusessem seus bons ofícios junto dos Médicis a fim de que êstes lhe dessem alguma ocupação, nem que fôsse a de "voltolare un sasso". Uma das finalidades visadas com a composição de II Principe, foi, sem dúvida, a de ser convidado a tomar parte de nôvo na política. Para ter certeza disto é suficiente ler as últimas palavras da dedicatória "ao magnífico Lourenço de Médicis" (19):

"Se Vostra Magnificenzia dallo apice della sua altezza qualche volta volgerà gli occhi in questi luoghi bassi, conoscerà quanto io indegnamente sopporti una grande e continua malignità di fortuna" (20).

Em 1519, por instância do papa Leão $X(21)$, escreveu o Discorso sopra il riformare lo Stato di Firenze. Paulatinamente, - exilio de Maquiavel ficou mais brando; o escritor podia voltar - Florença de vez em quando, visitar os amigos e o círculo de estudiosos "Orti Oricellari", na casa dos Rucellai.

Finalmente, em 1520, o govêrno medíceo enviou Maquiavel a Lucca, confiando-lhe uma modestíssima missão diplomática, que ocasionou a composição do Sommario delle cose della città di Lucca e da Vita di Castruccio Castracani. Também de pouca monta foi a missão de observador junto do capitulo franciscano, em Carpi, que Maquiavel, zombeteiramente, definiu "a república dos tamancos". Mais importante, ao invés, foi a incumbência recebida do Estudo Florentino (22), por sugestão de Júlio de Médicis, de escrever "os anais ou então a história das coisas feitas pelo Estado e cidade de Florença, desde o tempo que Ihe parecesse mais conveniente e em língua latina ou toscana, conforme êle quisesse". Nasceram, assim, as Istorie fiorentine, que, em 1525, Maquiavel apresentava a Júlio de Médicis, já eleito papa com o nome de Clemente VII.

Maquiavel entrava de nôvo na política e sua atividade foi bastante intensa; mas uma nova tempestade pairava sôbre a ltá-

19) Lourenço de Médicis, duque de Urbino, que não deve ser confundido com Lourenço o Magnífico.

20) Palavras que encerram a dedicatória de II Principe.

21) Giovanni de' Medici, filho de Lourenço o Magnífico; tornou-se papa e tomou o nome de Leão $X$.

22) Ainda hoje a Universidade de Florença conserva oficiolmente êste nome. 
lia e Florença. As tropas de Carlos $V$ e os arcabuzeiros de Frundsberg põem a península mediterrânea a ferro e fogo; Roma é devastada pelo terrível saque de 1527 (23).

Em Florença, o povo levanta-se contra os Médicis, arrancaIhes o poder e proclama a república (1527). Maquiavel, que havia colaborado de certo modo com os Médicis, foi privado de todos seus encargos. Profundomente desiludido, entristecido e doente, falecia poucos dias depois. Pedro, um de seus filhos, dando a notícia a um parente, escreve: "Faleceu Nicolau, nosso pai... Confessou seus pecados a frei Mateus, que lhe fêz companhia até a morte. O nosso pai nos deixou na máxima pobreza".

\section{O LITERATO, O LINGÜISTA, O HISTORIADOR}

Nem todos concordarão com Papini, quando afirma que "entre todos os prosadores italianos de todos os séculos e de tôdas as cidades, Nicolau Maquiavel é, sem permissão de réplica, o maior" (24). No entanto é de se convir que Maquiavel deve sua fama não à sua otuaçāo política, mas às obras que escreveu (25).

Êsse escritor, diz Rosário Tosto, relatando o que nos transmitiram os biógrafos, era "de estatura normal, magro, de rosto pálido e cabelo prêto, de olhos também prêtos e extremomente vivos. Os que o conheciom achavam-no sábio e prudente, alegre e amável, amiúde arguto e zombeteiro, por vêzes frívolo em sua vida particular, mas muito sério no cumprimento de seus deveres públicos. Sob a máscara do político e do diplomata, aparentemente frio, cínico e indiferente, houve sempre nêle um espirito rico de sentimento e amante da pátria, disposto a sofrer, a esperar e a se iludir com grande ingenuidade. Por isso, nascera

23) Minuciosa análise histórica daqueles tempos dramàticamente agitados fèz um erudito historiógrafo do Universidade Federal do Poraná. Cf. Cecilio Morio WESTPHALEN, Corlos-Quinto (1500-1558) - Seu Império Universal, Curitibo, 1955, ps. 99-151.

24) Giovanni PAPINI, ob. cit., p. 97.

25) Obras de Nicolou Maquiavel: Discorso sopra le cose di Pisa (1499); Del modo di trattare i popoli della Valdichiana ribellati (1502); Descrizione del modo tenuto dal duca Valentino nello ammazzare Vitellozzo Vitelli, Oliverotto da Fermo, il signor Pagolo e il duca di Gravina Orsini (1503); Discorso sopro la provvisione del danaro (1503); Decennale primo (1504); Relazione sulla istituzione della nuova Milizia (1506); Ritratti delle cose dell'Alemagna (1508-1512); Decennale secondo (1509); Ritratti delle cose della Francia (1510); il Principe (1513); Discorsi sopra la prima deca di T. Livio (começados em 1513); Lo Mandragolo (1513); L'Asino d'oro (1517): Lo Clizia (1517); Discorso sopra il riformare lo Stato di Firenze (1520); Sommario delle cose della città di Lucco (1520); Vita di Costruccio Costracani (1520); Dell'arte della guerra (1520); Istorie fiorentine lacabadas em 1525). O Dialogo sulla lingua e a Novella di Belfagor forom compostos antes de 1516, conforme a opiniōo de criticos autorizados. 
não para a ação, como êle pensava, mas escritor e pensador, mais apto a estudar do que a fazer política" (26).

O ambiente da culta Florença, em que viveu, facultou-lhe adquirir bons conhecimentos lingüísticos e literários. Apesar disto, sua língua conservou sempre algo de popular; nem por isso ficou prejudicada a elegância de sua expressão rápida e nervosa.

Bom conhecedor do latim, lia com facilidade as obras dos autores romanos, especialmente as de Tácito e Livio, cujo reflexo pode ser encontrado na estrutura de seu período conciso e abundante em subordinações.

A vida pública, a freqüentação de homens doutos e poderosos, o contato com os governantes, o manejo dos negócios foram uma lição contínua para Maquiavel, e ofereceram-lhe rica matéria para a reflexão. O estudo da história romana colocou-o em contato com um mundo diverso e distante e proporcionou-lhe a oportunidade de comparar os modernos com os antigos. Maquiavel parece ter maior admiração e simpatia pelo mundo antigo.

Os assuntos históricos e políticos, e os que com êles se relocionam, foram os que atraíram êsse escritor. A porção maior e melhor de sua produção literária é, por conseguinte, dedicada a êles, como é fácil de se ver, percorrendo a lista dos títulos de suos obras.

No entanto, Maquiavel dedicou-se também à literatura de ficção, escrevendo sonetos, cantos carnavalescos, capítulos em tercetos, a novela de Belfagor, o modesto poemeto Asino d'oro, duas comédias, das quais uma - La Mandràgola (1513) - é especialmente louvada pela crítica mais abalizada. Além disso, escreveu muitas cartas, algumas para tratar de negócios públicos, outras paro manifestar seus sentimentos íntimos aos amigos e aos familiares. Enfim, é preciso mencionar ainda o Dialogo sulla lingua (1514?).

$E^{\prime}$ evidente que o valor literário de todos êstes escritos va. ria muito, ainda que sua linguagem conserve sempre o timbre caracteristico da prosa maquiavélica. Mais cuidada e literária é a prosa dos Discorsi e das Istorie fiorentine; sêca, nua, cortante a de II Principe. Característica geral da prosa maquiavélica é a falta de estudadas ornamentações literárias. O autor vai atrás da matéria, da coisa, não da palavra. E' fácil de se entender como a sua prosa não exerça grande atração sôbre os moços, mas capte a atenção do homem adulto e amadurecido pela experiência das coisas humanas.

Por ser um escritor extremamente temperamental, pessoal, Maquiavel carece de imitações estilísticas; e visto que, acima de

26) Rosário TOSTO, Hisfória da Literatura Italiana, tradução de Luígi CASTAGNOLA, cit., p. 38. 
tudo, queria ser entendido por todo o mundo, usou uma língua popular, depurada pela habilidade de quem possuía formação humanística e tinha a consciência e a vontade de ser escritor. A parte lexical da linguagem de Maquiavel é bastante tradicional. Giàcomo Devoto afirmo com autoridade: "A sua morfologia não é nem tradicionalista, aderente aos moldes de Boccàccio, nem onarcóide. Ela aceito uma fonte, a florentina popular" (27).

Maquiavel teve consciência de sua atuação literária e, também por causa disto, interessou-se pela questão da língua um assunto polêmico em que tomaram parte todos os escritores importantes de Quinhentos. Desfraldou a bandeira do "florentinismo", tornando-se um dos mais decididos foutores desta corrente. Para defender o seu ponto de visto, escreveu o Discorso ovvero dialogo in cui si esamina se la lingua in cui scrissero Dante, il Boccàccio e il Petrarca si debba chiamare italiana o fiorentina.

Maquiovel chama de "pouco honestos" os que pretendem chamar de "língua toscana" a língua usada pelos escritores da península italiana, e de inonestissimi os que pretendem chamá-la de "língua italiana". Pois, a língua que usaram os Trecentistas era a língua florentina, os que imitaram os Trecentistas usaram o florentino; por conseguinte, a língua usada pelos literatos peninsulares, em quolquer lugar êles se encontrem, visto que imitam os trecentistas florentinos, deve ser chamada, com justiça, língua florentina, e não lingua italiana, nem língua toscana, nem língua das côrtes. Os argumentos de Maquiavel, discursando sôbre esta famosa questão, não carecem de lógica e de valor, no conjunto; opesar de tudo isto, a história consagrou a expressão "lingua italiana" (28).

Maquiavel foi também historiador. Versam assuntos históricos: Decennale primo, Decennale secondo, Vita di Castruccio Castracani, Istorie fiorentine. Os dois primeiros escritos, em tercetos, têm escasso valor histórico. A Vita di Castruccio Castracani levantou críticas e polêmicas diversas; de fato, não respeita muito a verdade e aproxima-se do biografia romanceada, à maneira das célebres vidas plutarquianas. De sorte que o valor de Maquiavel, como historiador, está ligado às Istorie fiorentine.

Esta obra, em oito livros, parte da época das invasões bárbaras e chega até o ono de 1492, isto é, até a morte de Lourenço o Magnífico. A crítica histórica demonstrou que Maquiavel nem sempre relata os fatos com respeito da verdade; às vêzes oté altera ou falseia os acontecimentos de propósito "para achar

27) Giocomo DEVOTO, Profilo di Storia Linguistica Italiano, Florença, 1960, p. 82.

28) Cf. a obra fundamental de Bruno MIGLIORINI, Storia della Lingua Italiana, Florenca, ps. 351-352. 
nêles uma demonstração e exemplificação das suas teorias sôbre a política e a vida humana" (29). Seja como fôr, trata-se de uma obra preciosa, também porque ajuda a comprender methor a mentalidade de Maquiavel em julgar fatos, homens e acontecimentos.

\section{O PENSADOR POLITICO: IL PRINCIPE.}

O pensamento político de Maquiavel está contido, especialmente, nos Discorsi e no Principe. Exominaremos sòmente o conteúdo do Principe, por ser mais importante e conter, implicitamente, todo o pensamento político de Maquiavel.

II Principe não é um tratado de filosofia política. Nem Maquiavel é, na verdade, um filósofo da política. E' tese exaustivamente demonstrada por Nicola Petruzzéllis que Maquiavel, se falarmos com rigor de têrmos, não é um filósofo, nem sequer da política, por faltar-lhe a visão universal das coisas, exigência imprescindivel para construir qualquer filosofia.

II Principe é um pequeno volume, em vinte e seis capitulos, composto em 1513, durante o exílio político, na sua casa de Sant'Andrea in Percussina. Na dedicatória ao Magnifico Lourenço de Médicis, Maquiavel afirma que não pode oferecer-lhe coisa mais valiosa; pois, o volume contém "la cognizione delle azioni degli uomini grandi imparata da me con una lunga esperienzia delle cose moderne e una continua lezione delle antiche" (30). $\mathrm{Na}$ primeira parte (|-X|), Maquiavel trata das diversas formas de estados - ou principados - dos diversos modos de conquistá-los e governá-los; na segunda (XII-XIV), trata das milícias mercenárias, auxiliares, mistas e nacionais; na terceira ( $X V-X X V)$, da arte de governar; no último capítulo é contida uma exortação aos Italianos a fim de que cerrem fileiras em volta da casa dos Médicis para libertar a península dos povos invasores.

1. Todos os estados são repúblicas ou principados. Êstes últimos são hereditários ou novos ou mistos. Os estados se podem conquistar combatendo com milícias próprias ou de outrem, ou então pela virtude ou pela fortuna.

Deixando de lado as formas republicanas de govêrno, das quais falou nos Discorsi, Maquiavel passa a tratar sòmente dos principados. Nos estados hereditários encontram-se menores dificuldades do que nos novos, porque o príncipe hereditário tem menor ocasião de ofender, graços à continuidade do domínio.

As dificuldades estão nos estados novos ou mistos, pelo fato de que o povo conquistado, quando vê que sob o príncipe nôvo passa pior do que antes, se revolta. Vê-se então o príncipe

29) Rosário TOSTO, ob. cit., p. 47.

30) II Principe - Dedicatória. 
obrigado a ofender os súditos, para manter o estado, sem poder tomar medidas enérgicas contra os que o ajudaram na conquista, por ser-lhes obrigado. Quando os estados têm a mesma língua e pertencem ò mesma província, é fácil conservá-los, e para possuí-los firmemente basta eliminar a dinastia do príncipe que os dominava antes. Quando têm língua, costumes e organizações diferentes, a melhor providência é o príncipe ir habitar nêles, ou enviar colônias, ou mandar tropos estáveis. $E^{\prime}$ melhor mandar colônias do que tropas; pois, estas custom muito, empobrecem o príncipe e ofendem muita gente, ao passo que as colônias custam poucos e ofendem uma parte mínima da população. Os poucos ofendidos e despojados, ficando pobres e dispersos, não podem vingar-se. Com efeito, os homens se devem acariciar ou eliminar, porque, quando a ofensa é pequena, êles se podem vingor, mos se forem eliminados de uma vez nada mais podem êles fazer. $E^{\prime}$ preciso ainda que o príncipe se torne amigo e defensor dos vizinhos pouco poderosos, enfraque. ça os habitontes mais influentes, e de maneira alguma permita que entre naquele estado conquistado um outro príncipe tanto poderoso quanto êle. $E^{\prime}$ coisa natural querer conquistar novos estados; os que o podem fazer e o fizerem, serão sempre louvados; mas os que não podem e querem fazê-lo a qualquer custo, cometem grave êrro e serão desaprovados por todos.

A Fronça engrandeceu, na Itália, a Igreja e a Espanha, e estas, por sua vez, causaram a ruina da França na Itálio. Dêste fato se pode tirar uma regra geral de politica, a qual nunca ou raramente falha: quem torna alguém poderoso, rui, porque o nôvo poderoso desconfia de quem o tornou tal.

A história mostra que há dois sistemas diferentes de governar: o despotismo absoluto, em que todo o poder está concentrado no rei - como no caso de Dario; ou a monarquia de tipo feudal, em que o rei governa por meio dos barões - como no caso da França. Alexandre Magno travou guerras terriveis para conquistar o reino de Dario; mas, uma vez conquistado, sendo morto Dario, o povo não se revoltou contra os sucessores de Alexandre, por ser governado como escravo e sem liberdade. As coisas correm diversamente nos reinos de tipo francês. Aqui é fácil entror, convidado por algum dos barões insatisfeitos; mas depois de entrado, é quose impossivel ficar. Com efeito, mesmo após a eliminação da dinastia real, ficam os barões acostumados a mandar e viver em liberdade, sempre prontos a chefiar revoltas, não sendo possivel contentar ou eliminar todos êles.

Para o principe conservar os estados conquistados, quando antes acostumados a viver em liberdade e conforme suas leis, é preciso: destruí-los, ou ir habitar nêles, ou criar dentro dêles uma oligarquia amiga que os governe, a fim de tirar vantagens econômicas. Na verdode, quando o estado conquistado fôr uma 
república livre, deve ser destruida pelo príncipe, porque do contrário, será êle destruído pela república conquistada; se fôr, porém, um principado, será suficiente eliminar a família do governante.

Os principados totalmente novos, conquistados pelas armas e pelo valor, serão fàcilmente conservados se o príncipe fôr valente e armado; do contrário, os perderá. De fato, é coisa muito difícil tornar-se chefe e impor novas organizações sociais; se - príncipe não estiver em condições de obrigar os súditos pela fôrça, quando se revoltarem, ruirá. Pois, os profetas armados raro periclitam, os desarmados são abatidos.

O príncipe que conquistar um estado pelas armas e vontade de outrem, ou por fortuna, tem que lutar pouco para a conquista, mas muito para se manter no poder. Com efeito, êste príncipe fica sempre ao léu da fortuna ou na dependência dos que the ofereceram o principado, a não ser que tenha capacidades e valor extraordinários.

Às vêzes um indvíduo particular pode tornar-se príncipe praticando crimes nefandos. Não se pode ainda chamar de virtude matar os cidadãos, atraiçoar os amigos, violar a palavra dada, ser sem piedade, sem religião. Êstes modos de agir podem fazer com que alguém conquiste império, mas não glória. Quem conquistar o estado com êstes meios, deve praticar tôdas as ofensas no comêço, de uma vez, e não aos poucos, ficando sempre com a faca na mão. Pois, praticados todos os crimes de uma vez, êsse príncipe deve procurar fazer com que os súditos esqueçam seus massacres, fazendo-lhes favores e ganhando-lhes a simpatia. As injúrias têm que ser feitas tôdas de uma vez, para que ofendam menos; os favores têm que ser feitos paulatinamente a fim de que sejam saboreados melhor.

Quando um cidadáo particular se torna príncipe de sua pátria pelo favor de seus concidadãos, há lugar o principado civil. Esta forma de principado nasce quando os grandes, querendo oprimir o povo, escolhem um dentre êles que o faça; ou então, quando o povo, não se podendo defender contra os grandes, escolhe um homem popular que o defenda contra a opressão dêles. Quem se torna príncipe com o favor dos grandes, se mantém com mais dificuldade, porque rodeado de muitos que pretendem ser-lhe iguais, e não os pode manusear como quer. Ao invés, quando um homem popular é feito príncipe pelo povo, está sòzinho no govêrno, todos lhe obedecem, pedindo sòmente defesa contra a opressão dos grandes. Em ambos os casos, o príncipe procure granjear o favor do povo, porque certamente ruirá se o povo o abandonar. Essses principados civis periclitam quando querem tornar-se despóticos. Pois, semelhante príncipe nõo se pode basear no que vê nos tempos quietos, quando cada cidadão lhe é obediente, corre, promete, quer morrer para êle, sendo a morte distante. Mas, no perigo, tudo corre bem diver- 
samente. Procure o príncipe civil fazer com que os súditos precisem sempre dêle, e, destarte, todos the ficorão fiéis.

Para defender seu estado, qualquer príncipe está numa destos situações: ou tem tropos suficientes para defender todo o seu território, ou então é obrigado a retirar-se nalguma cidade fortalecida. Neste segundo caso, o principe será vitorioso se tiver meios de defesa e viveres de reserva. Raro o cêrco durará mais de um ano. O território será devastado no comêço, quando os ânimos estão dispostos a lutar; depois os súditos, para recuperar suas coisas, ficarão fiéis ao principe, estreitando-se em tôrno dêle. Se o principe fôr valente e animoso, superaró as dificuldades, mostrando aos súditos que o mal seró curto, alimentando as esperanças do futuro, salientando a crueldade do inimigo, prometendo a todos a recuperação dos haveres. Destarte o príncipe poderá manter seu estado.

Resta falar sòmente dos principados eclesiásticos. As dificuldades, aqui, estão só antes da conquista. Conquistados por virtude ou por fortuna, êsses principados sem elas são mantidos, sendo sustentados pelas instituiçōes antigas da religiāo, tão poderosas e firmes que mantêm seus príncipes à testo do estado, seja qual fôr seu modo de proceder e de viver. Sòmente êles têm estados e não os defendem; súditos e não os governam. Os estados, por não serem defendidos, não lhes são tirados; os súditos, por não serem governados, não se importam com os príncipes. Ésses estados sòmente são felizes e seguros. Sendo tais estados regidos por cousas superiores, que escapam à mente humana, é supérfluo falar dêles. Visto que são constituídos e mantidos por Deus, seria tarefa de homem presunçoso e temerário discursar sôbre êles.

II. A segunda parte do Principe trata dos milícias. Tôdas as formos de estado têm que ter, além de boas leis, também boas milícias.

O principe defende seu estado com milícias próprias, ou mercenários, ou auxiliares, ou mistas. As mercenárias e os auxiliares são inúteis e perigosas. As mercenárias despojam o príncipe na paz, e fogem na guerra; elas servem o príncipe pelo salário, que não é suficiente a fazer com que elas queiram morrer na batalha. As auxiliares são mais perigosas ainda do que as mercenárias, porque unidas e dependentes de um principe estrangeiro; de sorte que causam quase sempre a ruina de quem - elas recorre. As mercenárias são perigosas pela preguiça, as auxiliares pelo valor.

Um príncipe sábio, portanto, deve servir-se de tropas próprias, se quiser manter-se no poder. Sendo a questão das milicias de grande importância, o príncipe deve sempre pensar nela e na guerra. Pois a guerra é a única coisa que the condiz. Com a guerra até individuos particulares conquistaram principados, e 
príncipes perderam o estado por não terem pensado contìnuamente na guerra.

III. Na terceira parte da obra, Maquiavel trata de como deve comportar-se um príncipe para com os súditos e os amigos. $E^{\prime}$ a parte mais debatida e incriminada do Principe.

Muitos escreveram sôbre o assunto, diz Maquiavel, mas de um modo teórico e, portanto, fantástico. Falaram de estados e repúblicas que nunca existiram na realidade, mas sòmente na imaginação dêles. Querendo, portanto, escrever coisa útil para quem tiver capocidade de a entender, pareceu melhor ao Autor limitar sua indagação "alla verità effettuale della cosa" e não ir atrás da sua imaginação.

"Molti si sono imaginati republiche e principati che non si sono mai visti né conosciuti essere in vero; perché egli è tanto discosto da come si vive a come si doverrebbe vivere, che colui che lascia quello che si fa per quello che si doverrebbe fare impara piuttosto la ruina che la perservazione sua: perché uno uomo, che voglia fare in tutte le parte professione di buono, conviene ruini infra tanti che non sono buoni. Onde è necessario a uno principe, volendosi mantenere, imparare a potere essere non buono, e usarlo e non l'usare secondo la necessità" (31).

Todos os homens, especialmente os príncipes, têm qualidades boas e más; melhor seria que, no príncipe, se encontrassem sòmente as qualidades boas, mas visto que é impossível, pela condição humana que não o consente, deve êle evitar sòmente os vícios que the poderiam tirar o estado, e abandonar-se aos vicios sem os quais dificilmente poderia salvá-lo.

Um príncipe deve ser considerado liberal, mas doando tãosòmente os haveres dos outros e não os seus, porque, neste caso, tornar-se-ia pobre e, por conseguinte, desprezado.

Seria melhor que o príncipe fôsse considerado compassivo e não cruel. No entanto, não se importe com a fama de cruel, quando a crueldade é útil para conservar o estado. Os homens respeitam mais quem se faz temer, sem despertar o ódio. O príncipe conseguirá isto respeitando as mulheres e, especialmente, os haveres dos súditos, porque os homens esquecem mais de pressa a morte do pai do que a perda do patrimônio. 
"Quanto sia laulabile in uno principe mantenere la fede e vivere con integrità e non con astuzia, ciascuno lo intende; nondimanco, si vede per esperienza ne' tempi nostri quelli principi avere fatto gran cose che della fede hanno tenuto poco conto, e che hanno saputo con I'astuzio aggirare e' cervelli degli uomini; e alla fine hanno superato quelli che si sono fondati in sulla lealtà" (32).

Procure o príncipe, portanto, combater os adversários com as leis - o que é próprio do homem; e quando necessório fôr, com a fôrça bruto - o que é próprio dos animais. Imite, pois, - lec̃o e a rapôsa; isto é, use da fôrça bruta ou da fraude conforme as circunstâncias. O leão, só com a fôrça, não sabe defender-se contra as armadilhas; tem que recorrer à astúcia da rapôsa que, recorrendo à fraude, se defende contra os lôbos, mais fortes do que ela.

"Non può, pertanto, uno signore prudente né debbe osservare la fede, quando tale osservanzia li torni contro e che sono spente le cagioni che la feciono promettere. $E$, se gli uomini fussino tutti buoni, questo precetto non sarebbe buono; ma, perché sono tristi e non la osservarebbono a te, tu etiam non l'hai ad osservare a loro. Né mai a uno principe mancorono cagioni legittime di colorire la inosservanzia" (33).

Um príncipe deve, portanto, parecer misericordioso, fiel, humano, integro, religioso e sê-lo; mas deve ser tudo o contrário quando a manutençāo do estado o exigir. Seja, pois, grande simulador, porque os homens são tão tolos que quem engana acha sempre quem se deixa enganar.

"Focci dunque uno principe di vincere e mantenere lo stato: e' mezzi saranno sempre iudicati onorevoli e da cioscuno laudati; perché il vulgo ne va sempre presa con quello che pare e con lo evento della cosa; e nel mondo non è se non vulgo" (34).

O príncipe deve, afinal, evitar tudo o que o pode tornar odioso diante do povo; combater dentro do estado tudo o que poderia tirar-lhe o poder; estar sempre em guarda contra os poderosos que estão fora do estado. Sendo amado pelo povo, não

32) II Principe, XVIII.

33) II Principe, XVIII.

34) II Principe, XVIII. 
haverá perigo de conjurações, e possuíndo um bom exército próprio e aliados, defender-se-á contra os inimigos de fora.

Faça tudo o possível o príncipe para armar os súditos afeiçoados e desarmar sempre os inimigos. Nenhuma coisa torna o príncipe mais estimado do que os grandes empreendimentos; na política interna faça coisas extraordinárias que o engrandeçam; na política externa tome partido firme em favor de quem é mais poderoso e amigo. Faça com que os súditos possam exercer tranqüilamente seus negócios, e ofereça ao povo espetáculos e diversões. Tem grande importância a escolha dos ministros, e os súditos julgam o príncipe pelo tipo de pessoas de que se rodeia. Se um ministro pensa mais em si do que no príncipe, deve ser afastado, poque é certo que tal ministro procura o seu interêsse e a ruina do príncipe.

Evite a peste dos aduladores, e tome conselhos dos homens sábios, mas quando êle quer, e não quando êles querem. Saiba, porém, que seus conselheiros procurarão sempre o interêsse dêles, visto que os homens são sempre maus, se alguma necessidade não os torna forçosamente bons.

Os principes da Itália que perderam seus estados, devem culpar-se a si mesmos, porque não observaram os preceitos e os conselhos contidos no Principe. Muitos pensaram que as coisas do mundo são governadas pela fortuna e por Deus; julgaram, por conseguinte, que o príncipe não deve matar-se a si mesmo com as preocupações do govêrno, mas confiar na sorte. Maquiavel diz que, às vêzes, êle mesmo estava inclinado a pensar desta forma. Mas a verdade é diferente. A fortuna, a sorte governam, por vêzes, nossas ações; nosso livre arbítrio, porém, é o artífice verdadeiro dos acontecimentos.

No capitulo final, Maquiavel exorta os príncipes italianos a serrar fileiras em tôrno da poderosa casa dos Médicis, que parece ter, no momento, uma especial proteção de Deus, a fim de libertar a península mediterrânea dos povos invasores. Com efeito, tornaram êles a Itália mais escrava de que os Hebreus, mais oprimida do que os Persas, mais desagregada do que os Atenienses, sem chefe, sem ordem, batida, despojada, dilacerada, coberta de ruínas fumegantes.

\section{CONSIDERAÇÕES CRITICAS}

Maquiavel ocupa um lugar de destaque na literatura italiana, e pode ser considerado o maior prosador que teve a Itália nos fins de Quatrocentos e começos de Quinhentos. E isto fica de pé, apesar de sua língua ter certo timbre popular e desenvoltura libertária, que não chegaram a prejudicar a elegância literária da expressão. 
Suas idéias sôbre a questão da língua, que manteve em polvorosa os literatos de Quinhentos, são válidas e bem estruturadas, no conjunto, embora a tradição não tenha aceito a opinião de Maquiavel, que pretendia chamar de "língua florentina" a língua italiana.

Como historiador, Maquiavel não alcançou o valor e os méritos que granjeou como literato. Na verdade, por vêzes, alterou os fatos, de propósito, para curvá-los a servir de provas para suas teorias políticas. Mesmo assim, as Istorie fiorentine ficam uma obra de vulto e preciosa.

Maquiavel, digam o que queiram alguns de seus apologistas, não foi um filósofo, no sentido verdadeiro da palovra. Nem êle tinho esta pretensão. Mas seu pensamento político presta-se à construção de uma filosofia política que, vàriamente ampliada pelos seus continuadores, anda pelo mundo com o nome de maquiavelismo. Contudo, é ato de justiça para com Maquiavel, nõo atribuìir ao autor florentino tudo o que vai sob o rótulo de maquiave! ismo.

O pensamento político de Maquiavel está, especialmente, no Principe, um livro vulcânico pelos assuntos que versa. Não é coisa fácil, no entanto, penetrar sempre exatamente no sentido desta obra. Papini o entendeu assim: "Quando o naturalista escreve um livro sôbre os tigres e os jaguares ninguém pode exigir que atribua a êstes elegantes felinos os costumes dos coelhos $e$ dos castores e, pela mesma razão, ninguém pode pregar na cruz Maquiavel se, querendo escrever um tratado sôbre os príncipes e tendo dionte dos olhos os senhores da Renascença, não os pintou como outros tantos amorosos pastôres obedientes aos princípios da caridade, da justiça e da democracia. Ele diz: se nestes tempos, dadas estas condições dos homens e dos estados, alguém quer se tornar príncipe ou, se já o é, tal quer ficar a despeito dos inimigos, deve comportar-se desta maneira, e ter presentes êstes preceitos tirados da experiência. E não quero dizer se êstes preceitos são cristãos ou pagãos, morais ou imorais, angélicos ou infames: mas são os que se ajustam à finalidade e isto basta" (35). Emboro demasiadamente categórico, pode-se dizer que há muita substância de verdade neste juízo sôbre o Principe. Maquiavel viveu numa época de ferro, por um lado esplendorosa e por outro lado briguenta, nefanda, sanguinária, retumbante de guerras, manchada de traições para a Itália (36). E' uma circunstância que não deve ser esquecida para a justa compreensão de Maquiovel. Não nega êle a possibilidade de um mundo político estruturado numa concepção transcendente da realidade.

35) Giovonni PAPINI, ob. cił., p. 92.

36) Além das guerras entre a França e a Espanha, travadas na península, a Itália vivio os tempos de Alexandre VI e de César Borja. 
Desta concepção transcendente quis êle, porém, prescindir completamente na sua indagação, e separando assim a política da ética deslustrou e tornou caduca grande parte de seu pensamento político.

Mais uma crítica, dialèticamente irrespondível, da racionalização técnica da vida política, alicerçada nos moldes maquiavélicos, foi feita, ainda há pouco, por Maritain (37). A fôrça do maquiavelismo provém das contínuas vitórias dos meios perversos no mundo político, e da opinião de que os príncipes e as nações que respeitam a justiça são escravizados por aquêles que confiam na perfídia e praticam a violência. Mas, na verdade, é posível praticar a justiça e ser forte e prudente.

Mesmo numa sociedade regressiva e bárbara, em que a humanidade fôsse forçada a viver num universo concentracionário, como num imenso campo de Buchenwald, a única possível salvação pode vir sòmente da observância da lei moral. "A pior tentação que se depara à humanidade, nas épocas de noite escura e de crise universal, é abandonar a Razão Moral" (38). O homem não pode abdicar impunemente de sua natureza, que não é a das feras. As tentativas feitas para viver como as feras, custaram sangue à humanidade, que sempre teve que voltar aos princípios da ética para sair do caos em que a lançaram aquelas tentativas de vida animalesca ou teromorfa.

$E^{\prime}$ possível criticar as doutrinas políticas de Maquiavel, mas ùnicamente com base numa concepção transcendente da vida e do homem. Quem admite só uma concepção materialista da realidade não pode, na lógica de seu sistema, criticar ou recusar Maquiavel, cuja filosofia política "não está em contraste com a ética humanista e imanentista, que nõo tem fim transcendente e leis morais estáveis" (39).

O Principe versa problemas universais, pois, e sempre de premente atualidade. Ontem como hoje, há homens que pretendem governar a qualquer custo $(40)$, não recuam diante de nenhum obstáculo e chegam até cercear qualquer pensamento di-

37) Cf. Jocques MARITAIN, ab. cit., ps. 70-90.

38) Jacques MARITAIN, ob. cit., p. 90.

39) U. PADOVANI-L. CASTAGNOLA, Histório da Filosofio, São Paulo, 1967, 7. a ediçāo, p. 273.

40) Os chefes comunistas, que pretendiam ser os defensores do povo, são os mais sedentos de mando e os mais agarrados ao poder. Basta ler o que escreve Svetlano, filho de Stalin. "Penso que a principal influência maléfico (sôbre meu pai) tenho sido aquela terrível luto pelo poder que êle travou durante tớda a vida". Cf. Perché sono fuggita, em Epoca Milão, 1967, N. ${ }^{\circ} 884$, p. 39. 
vergente para segurar nas mãos o poder (41). Nem se pode dizer que tamanho zêlo tenha por movente a promoção do bem-estar popular ou o interêsse dos súditos.

Uma correta filosofia da política tem muito que esclarecer aos povos do nosso século. Se Maquiavel oferecer ocasião para solucionar satisfatòriamente os problemas políticos, terá contribuido, também êle, paro o nosso melhoramento.

41) Milovan Djilas, já teórico da filosofia politica comunista, escreve na sua obra A Nova Classe: "A aniquilaçōo de todo o pensomento divergente, o monopólio do pensamento com o propósito de defender seus interêsses pessoois, levarāo os comunistos à cruz do vergonho no história". M. D. A Nova Classs, traduçāo de Waltensir DUTRA, Rio de Janeiro, 1958, p. 204 . 